\title{
HIGH JEWELRY BRAND GRAFF: KEY FEATURES OF BUSINESS STRATEGY
}

\author{
Strelchenko Candidate of Economic Sciences (PhD), Associate Professor of Department \\ Elena \\ of Economics, Southern Federal University (88, M. Gorkiy St., Rostov-on-Don, \\ Aleksandrovna \\ 344002, Russian Federation). E-mail: estrelchenko@sfedu.ru
}

\section{Abstract}

The paper analyses luxury market on the example of world-known high jewelry brand Graff. The author introduces the company's business strategies and its distinguishing features from main rivals. The results of the research emphasized key points of the particular brand success, such as vertical integration, direct access to raw gems, dedication to quality, etc.

Keywords: luxury, jewelry market, business strategy, case-study, brand, Graff, brand success, management structure, public company.

\section{Introduction}

Through the history one of the main attribute of the wealth has been high jewelry that has become the symbol of luxury. High jewelry industry can be analyzed as a representative of nowadays luxury business that is supported by Hudders, Pandelaere [4]. According to Papiryan [10], jewelry and watches are the most profitable branches of luxury business. Typical example of the company acting in this segment is Graff that became a synonymous with the most expensive jewels in the world. As a vertically integrated company, its operations comprise all stages of manufacturing of high and high jewelry and watches and following retail through own stores chain [5].

The authors basing on data obtained from open statistical sources such as Graff's web proof information and official annual reports of its rivals conducted descriptive analysis of luxury market on the example of Graff company.

\section{Methodology}

The reason why Graff Diamonds is interesting as an object of academic research is that the Graff is an example of a company development from entering market as a small local family-owned enterprise to transforming into leader of the industry without changing values of company and its management structure [13]. Moreover, Graff is the only company in the segment of high jewelry which controls all stages of production - starting with extraction of rough gems through polishing and faceting, creating jewelry and finishing with retail. All other competitors in high level jewelry such as Tiffany, Harry Winston, Cartier, Bulgari are producing only final goods and have to purchase already facetted gems in auctions or through wholesalers [1]. Therefore, on the one hand Graff takes risk of faceting gems, but on the other hand, controlling the whole value chain allows Graff to reduce costs avoiding intermediaries, to have access to the best rough stones, and to control quality in all stages [14].

\section{Graff company's overview and key features}

Graff is considered to be one of the world's foremost diamond companies and is recognized for its expertise in the field of rare and important diamonds. These features allowed it to develop the large and unique inventory of gem quality diamonds that has become a hallmark of its business. It has acquired, cut and polished and sold many of the world's largest diamonds. As it is well discussed in academic literature, consumer base of high jewelry brands mostly is comprised of high and ultra high net worth individuals, to whom Graff provides the highest quality customer service [2; 3]. Graff sells its jewelry and watches through 18 directly operated stores and five carefully selected franchise partners operating from a further 13 locations in many of the exclusive shopping districts in cities across Europe, Asia and the United States [14]. Managing own chain of shops allow a company to control distribution of final goods and communication with clients [10]. Nevertheless, according to some academic literature luxury markets tend to distribute products not only via traditional shops, but also through international fairs and exhibitions that help to reduce costs [9].

One of the main distinguishing features of Graff is dirrect access to rough gems through acquisition of the diamond extracter Safdico. This stradegy allowed to construct independent supply chain of raw materials that supports stable position in the market [7; 10]. Rough diamonds and polished diamonds that Graff processes and which are not required for use in Graff jewelry are sold to third parties.

Graff is an example of a family-owned-company operating in the luxury market. Big part of its products represents unacceptable type of luxury [2]. For instance, as it is clear from table 1, 20\% of 2011 total revenue was earned by $\$ 10 \mathrm{mln}$ items [14]. As at 31 December 2011, they had inventory with a book value of US\$651.4 million, which included 708 individual white diamonds weighing over three carats each and 71 yellow diamonds weighing over seven carats each, most of which are contained in finished pieces of jewelry. 
Table 1. Graff price band table

\begin{tabular}{|c|c|c|c|c|c|c|c|c|c|}
\hline \multirow[b]{3}{*}{ Price Band } & \multicolumn{9}{|c|}{ Year ended 31 December } \\
\hline & \multicolumn{3}{|c|}{2009} & \multicolumn{3}{|c|}{2010} & \multicolumn{3}{|c|}{2011} \\
\hline & $\begin{array}{c}\text { Total } \\
\text { revenue }\end{array}$ & $\begin{array}{l}\text { \% of total } \\
\text { revenue }\end{array}$ & $\begin{array}{l}\text { \% of total } \\
\text { items sold }\end{array}$ & $\begin{array}{c}\text { Total } \\
\text { revenue }\end{array}$ & $\begin{array}{l}\text { \% of total } \\
\text { revenue }\end{array}$ & $\begin{array}{l}\text { \% of total } \\
\text { items sold }\end{array}$ & $\begin{array}{c}\text { Total } \\
\text { revenue }\end{array}$ & $\begin{array}{l}\text { \% of total } \\
\text { revenue }\end{array}$ & $\begin{array}{l}\text { \% of total } \\
\text { items sold }\end{array}$ \\
\hline & & & (in USS, & willions, en & ept parcentag & $\overline{\text { and total it }}$ & $\overline{m s \text { sold) }}$ & & \\
\hline US\$10 million and above $\ldots$. & 70.0 & 17.5 & 0.0 & 60.7 & 13.4 & 0.1 & 119.4 & 19.1 & 0.0 \\
\hline USS1 million - <US\$10 million . & 106.2 & 26.6 & 1.9 & 134,3 & 29.6 & 1.8 & 176.2 & 28.3 & 1.6 \\
\hline US\$100,000 - <US\$1 million . . & 160.6 & 40.2 & 20.2 & 192.1 & 42.3 & 18.7 & 230.2 & 36.9 & 16.6 \\
\hline Less than US\$100,000 . . . . . & 62.5 & 15.7 & 77.9 & 67.2 & 14.7 & 79.4 & 97.7 & 15.7 & 81.8 \\
\hline Total $\ldots \ldots \ldots \ldots \ldots \ldots$ & 399.3 & 100.0 & 100.0 & 454.3 & 100.0 & 100.0 & 623.5 & 100.0 & 100.0 \\
\hline Total items sold $\ldots \ldots \ldots \ldots \ldots$, & & 2,851 & & & 3,424 & & & 5,147 & \\
\hline
\end{tabular}

In order to understand a place of Graff in the industry it is useful to analyse and compare with one of the biggest players of the market - Tiffany \& co. Tiffany is public company with 313 shops and on-line shopping while Graff is fully owned by one family and have only 50 shops with no online shopping system. Despite the fact that the scales of these two companies are completely different, they are direct rivals. Considering data from latest published Tiffany's annual report one can see that gross profit is almost eight times larger than Graff has - \$15.8 million (according to data from [11]). Net sales of Graff are \$569.6 million in 2016, while Tiffany are five times larger as one can see from the table.

\begin{tabular}{|c|c|c|c|c|c|c|c|c|c|c|}
\hline $\begin{array}{l}\text { (in millions, except per share amounts, } \\
\text { percentages, ratios, stores and employees) }\end{array}$ & & $2016^{*}$ & & $2015^{\circ}$ & & $2014^{\mathrm{C}}$ & & $2013^{\circ}$ & & 2012 \\
\hline \multicolumn{11}{|l|}{ EARNINGS DATA } \\
\hline Net sales & $\$$ & $4,001.8$ & $\$$ & $4,104.9$ & $\$$ & $4,249.9$ & $\$$ & $4,031.1$ & $\$$ & $3,794.2$ \\
\hline Gross profit & & $2,490.3$ & & $2,491.3$ & & $2,537.2$ & & $2,340.4$ & & $2,163.3$ \\
\hline Selling. general \& administrative expenses & & 1.769 .1 & & 1.731 .2 & & $1,645.8$ & & 1.555 .9 & & 1.466 .1 \\
\hline Net earnings & & 446.1 & & 463.9 & & 484.2 & & 181.4 & & 416.2 \\
\hline Net earnings per difuted share & & 3.55 & & 3.59 & & 3.73 & & 1.41 & & 3.25 \\
\hline $\begin{array}{l}\text { Weighted-average number of difuted } \\
\text { common shares }\end{array}$ & & 125.5 & & 129.1 & & 129.9 & & 128.9 & & 127.9 \\
\hline
\end{tabular}

Table 2. Tiffany's selected financial data [1]

Moreover, the biggest distinguishing feature is, in contrast to Graff, Tiffany does not take aim only at high jewelry market and extra wealthy consumers. For instance, Tiffany provides mass market items such as silver jewelry. From the Table 3, it is clear that the half of Tiffany's sales comes from mass market items (fashion, jewelry and others). It is obvious that Tiffany uses its well-known brand to increase number of customers from different income segments while Graff is focusing only on high jewelry and highly valued among certain level clients because of extra quality and high level service.

Table 3. Tiffany \& co: sales of classes of similar products [1]

\begin{tabular}{lrrrr} 
& & & \multicolumn{2}{c}{ Years Ended January 31, } \\
\cline { 2 - 4 } (in millions) & & 2017 & 2016 & 2015 \\
\hline Net sales: & & & 870.4 \\
$\quad$ High, fine \& solitaire jewelry & $\$$ & $779.1 \$$ & $854.1 \$$ & $1,221.0$ \\
Engagement jewelry \& wedding bands & & $1,122.0$ & $1,142.2$ & 1.357 .6 \\
Fashion jewelry & $1,328.9$ & 1.340 .7 & 481.5 \\
Designer jewelry & 465.0 & 460.8 & 319.4 \\
All other & & 306.8 & 307.1 & 4.249 .9 \\
& $\$$ & $4,001.8 \$$ & $4.104 .9 \$$ & $\$$
\end{tabular}

\section{Results}

The foregoing overview showed following features of Graff. First of all, it is an strong brand name that was comprehensively created due to high quality and reputation. Since Graff was founded in 1960, the Graff brand has become synonymous with the most expensive jewels, and today is ranked among the top luxury jewelry brands by key industry publications, for instance "The Top 10 designer Jewelry Brands in 2018" 
by WP Diamonds, 2018. The Graff brand is positioned at the pinnacle of the luxury jewelry market, with a product offering unmatched by publicly traded hard luxury peers. The brand is underpinned by heritage of consistently high quality jewelry that blends truly exceptional diamonds with exquisite design and craftsmanship. The focus on target market of high and ultra high net worth customers has allowed Graff to maintain a high level of brand credibility, consistency and exclusivity which differentiates it from accessible luxury jewelry retailers.

Graff brand and position among the leading hard luxury goods retailers is reinforced by: an exceptional product offering of diamond jewelry and watches, with items priced above US $\$ 1$ million generating $47.4 \%$ of retail sales by value in 2011; a retail distribution network comprising 50 salons (18 directly operated stores and five franchise partners operating from 13 locations in many of the world's most exclusive retail shopping districts); regular participation at a number of the world's most exclusive luxury fairs; and consistently providing the highest levels of customer service that seeks to foster the development of long term, personal relationships, such that approximately $23.7 \%$ of the customers in 2011 , by number, had previously purchased jewelry or watches from Graff in one of previous years [14]. All in all, Graff managed to create customer loyalty, testifying further business increase [12].

Secondly, vertical integration with control over the key elements of the value chain can be named as the next distinguishing feature of business model. Diamond industry exists in condition of scarcity of raw materials that is mainly caused by two factors: rareness of rough diamonds and artificially created by De Beers lack of supply. In this environment all jewelry market players meet risk of unstable supply. Graff by acquisition of Safdico (one of the De Beers sightholders) controls rough diamond procurement. The sightholder system offers more price stability to both producers and sightholders while prices achieved through auctions are subject to short-term market dynamics and associated volatility. Being a sightholder confers a distinct advantage, as fewer than 100 sightholders work with the major producers and buy more than $70 \%$ of global diamond production. As a result, Graff controls the most critical elements of the value chain - supply of raw gems. It operates a highly developed sourcing system for both rough diamonds and polished diamonds on the open market, and operates state-of-the art cutting and polishing facilities through procurement and polishing division. This vertical integration has been essential to the development of the stable inventory and the successful expansion of the Graff brand. No other company among its rivals in the industry has achieved a similar level of integration.

The third feature is diamond inventory. Graff acquired and sold many of the world's largest, rarest, most renowned and historically significant diamonds. Over the last decade, Graff has built up an exceptional inventory of diamonds and finished pieces of jewelry, without particular regard to short term changes in demand, to enable it to supply the customers with the exceptional diamond jewelry. The continued maintenance of inventory sets Graff apart from the rivals by allowing Graff to offer clients a substantially larger selection of rare, high quality diamonds than could be offered by its competitors. Graff has established retail network in many of the most exclusive shopping destinations in the world (Harrods in London, Takashimaya in Tokyo, Hankyu Umeda in Osaka, TSUM in Moscow, etc) and participate in some of the world's most exclusive jewelry exhibitions in order to showcase exceptional inventory to elite customer base. According to Texeira, Pereira [12], it reflects one of dimensions of business growth. Graff provides a level of customer service that is unrivalled by the competitors, particularly in respect of the highest value items of jewelry in inventory, which Graff manages centrally and is therefore able to transport to any location in the world, including the homes of its customers [14].

\section{Conclusion and discussion}

Graff preserves its stability due to the unique position among its rivals: direct channels to rough gems and vertically integrated structure which allow to get access to the best gems and to control quality. Graff focuses on its brand image as a family company where all the clients are treated as family members getting highest service that helps to overcome industry obstacles, e.g. unstable supply of raw gems.

Considering the question - what helped Graff to reach leading positions in the high jewelry market, we would tend to think about following three reasons:

1. Structure of the company. Graff is not public company. On the one hand, it arises such issues as searching for additional finances for development. However, on the other hand, it can be seen as advantage. In contrast to large-scale companies as Tiffany, Graff is highly flexible in the scope of management since main decisions are taken by few members of one family.

2. Direct access to rough gems. Ownership of one the sightholders allows Graff to get access to stable supply of rough gems. That can be considered as the main strength distinguishing Graff from its rivals as well as vertical integration of all jewels production stages.

3. Concentration on the highest and finest segment of the market. In contrast to Tiffany or Cartier who are simultaneously produce and sell jewels for middle and high class clients as well as operating world- 
wide online shopping which can be not good for high brand image. Graff acts in the highest segment. Graff has created highly strong brand image operating in the highest luxury market. Also it supports its brand by purchasing almost all the biggest diamonds extracted nowadays.

For further development for Graff it would be reasonable to expand retail network to get benefits on fast growing Asian luxury demand (not only Japan but China) as well as to raise the global awareness of Graff's brand while remaining true to their heritage and high quality.

\section{References}

1. Annual report of Tiffany\&co of 2016 (published in 2017). Retrieved from: https://investor.tiffany.com/static-files/b46c8486-a789-49ac-b27a-a038f410939e.

2. Brun, A., Castelli, C., (2013), "The nature of luxury: a consumer perspective", International Journal of Retail \& Distribution Management, 41 (11/12), pp. 823-847.

3. Hudders, L., (2012), "Why the devil wears Prada: Consumers' purchase motives for luxuries", Journal of Brand Management, 19 (7), pp. 609-622.

4. Hudders L., Pandelaere, M., (2012), "The Silver Lining of Materialism: The Impact of Luxury Consumption on Subjective Well-Being", Journal of Happiness Studies, 13 (3), pp. 411-437.

5. Hudders, L., Pandelaere, M., Vyncke, P., (2013), "Consumer Meaning Making: The Meaning of Luxury Brands in a Democratised Luxury World", International Journal of Market Research, 55 (3), pp. 391-412.

6. Janssen, C., Vanhamme, J., Lindgreen, A., Lefebvre, C., (2014), "The Catch-22 of Responsible Luxury: Effects of Luxury Product Characteristics on Consumers' Perception of Fit with Corporate Social Responsibility", Journal of Business Ethics, 119 (1), pp. 45-57.

7. Luzzini, D., Ronchi, S., (2009), "Purchasing management in the luxury industry: organization and practices", Operations Management Research, 10.1007/s12063-009-0024-4, 3 (1-2), pp. 7-21.

8. Mosca, F., Giacosa, E., (2016), "Old and New Distribution Channels in the Luxury Sector", Global Marketing Strategies for the Promotion of Luxury Goods, 10.4018/978-1-4666-9958-8.ch010, pp. 220-243.

9. Official Web site of Graff Diamonds: https://www.graff.com.

10. Papiryan, G.A., (2006), "Corporate Strategies at the Global Industries of Luxury Goods", Journal of Russian Management, V. 4 (3), pp.155-170.

11. Rapaport Price List: Graff Diamonds Intl. Sales Slide in 2016. Retrieved from: https://www.diamonds.net/News/NewsItem.aspx?ArticleID=59071\&ArticleTitle=Graff+Diamonds+Intl .+Sales+Slide+in+2016

12. Texeira, C.S.B, Pereira, L.L.F., (2015), "Pereira Diamond: Benefits Management Framework", The International Journal of Business and Management, 3 (3), pp. 47-56.

13. Turunen, L.L.M., (2017), "Evolution of Global Luxury Brands", Interpretations of Luxury, 10.1007/978-3319-60870-9_3, pp. 31-59.

14. Web Proof Information Pack of Graff Company (2013). Retrieved from: https://www1.hkexnews.hk/listedco/listconews/sehk/2012/0528/ltn20120528026.pdf

Стрельченко Елена Александровна, кандидат экономических наук, доцент кафедры экономической теории экономического факультета, Южный федеральный университет (344002, Россия, г. Ростов-на-Дону, пр. Горького, 88). E-mail: estrelchenko@sfedu.ru

\section{ЮВЕЛИРНЫЙ БРЕНД GRAFF: КЛЮЧЕВЫЕ ЧЕРТЫ БИЗНЕС-СТРАТЕГИИ}

\section{Аннотация}

В статье проанализирован рынок роскоши на примере всемирно известного ювелирного бренда Graff. Авторы рассматривают бизнес-стратегии компании и ее отличительные по сравнению с основными конкурентами черты. Результаты исследования содержат ключевые позищи успеха данного бренда, такие как вертикальная интеграция, прямой доступ к сырью, управление качеством.

Ключевые слова: рынок роскоши, рынок ювелирных изделий, бизнес-стратегия, кейс-стади, бренд, Graff, успех бренда, структура управления, публичная компания. 